\title{
Suidae and Santheriidae from Wadi Moghra, early Miocene, Egypt
}

\author{
Martin Pickford, Ellen R. Miller, and Ahmed N. El-Barkooky \\ Acta Palaeontologica Polonica 55 (1), 2010: 1-11 doi: http://dx.doi.org/10.4202/app.2009.0015
}

New suid and sanithere material from Wadi Moghra, early Miocene, Egypt, is described and discussed.

The new material greatly improves the sample size and diversity of suoids known from North Africa, and includes one species of Sanitheriidae and three species of Kubanochoerinae. The Moghra suoid assemblage most closely resembles that from Gebel Zelten, Libya, suggesting that at least part of the Moghra deposits may overlap in time with part of Zelten, i.e., is equivalent in age to MN 4-5 of the European mammal zonation, or PIII of the East African one. Information from suids and sanitheres is consistent with previous interpretations, that the Moghra deposits were formed under swampy and littoral paleoenvironmental conditions.

Key words: Mammalia, Suidae, Sanitheriidae, biochronology, Miocene, Egypt, Africa.

Martin Pickford [pickford@mnhn.fr], Département Histoire de la Terre, Muséum

National d'Histoire Naturelle, 8, rue Buffon, 75005, Paris, France; Ellen R. Miller [millerer@wfu.edu ], Department of Anthropology, Wake Forest University, Winston

Salem, NC 27103, USA; Ahmed N. El-Barkooky [ahmed.el-Barkooky@shell.com], Geology

Department, Faculty of Sciences, Cairo University, Egypt.

This is an open-access article distributed under the terms of the Creative Commons Attribution License (for details please see creativecommons.org), which permits unrestricted use, distribution, and reproduction in any medium, provided the original author and source are credited. 

